\title{
A Chronological Overview of Some Ziwiye Belts
}

\author{
Alireza Hejebri Nobari ${ }^{1, *}$, Zahra Kouzegari ${ }^{1}$, Seyed Mehdi Mousavi ${ }^{1}$, Kamaleddin Niknami ${ }^{2}$ \\ ${ }^{1}$ Archaeology Department, Tarbiat Modares University, Iran \\ ${ }^{2}$ Archaeology Department, Tehran University, Iran
}

Copyright (C) 2015 Horizon Research Publishing All rights reserved.

\begin{abstract}
Ziwiye hoard has been the subject of many studies since its discovery in 1947 because of its remarkable works of art of various styles. Among these objects there are some metal plates, mainly made of gold. With some considerations, these plates could be attributed as belt fragments. Present study is on four fragmented belts of this group, including three gold belts and one bronze belt. The results show that along with their identical characteristics such as their rectangular forms and perforated borders, we can distinguish a variety of figurative styles on them executed either in repoussé or chased techniques. Base on the scenes depicted on these belts and their iconographical features, they could be studied in three groups: the first group, which chronologically stands earliest, is composed of the belts with scenes depicting ritual ceremonies composed of team or group of offering bearers. This group's ichnographical characteristics represent local Iranian features; the second, with the frieze of long passant animals (horned bulls) has distinctive ichnographical difference among the Ziwiye belts, these features recall figures (horned bulls) decorating Urartian bronze armors; the last group with animal figures represented with in a network pattern are the best example of mixture of Scythian and western Asiatic elements found in Ziwiye.
\end{abstract}

Keywords Ziwiye Hoard, Belt Fragments, Iconography, Classification

\section{Introduction}

In 1947, a treasure of remarkable works of gold, silver, bronze, ivory, stone and pottery objects was found by local peasants in a bronze coffin that has been buried below the ruins of a wall of an ancient citadel. The hoard was discovered near the village of Ziwiye, at about 55 kilometers south east of Saqqiz in Kurdistan province in northwestern Iran $[19,12]$. The majority of objects of the Ziwiye hoard were lost or destroyed. The few survived pieces were immediately sold in antique markets out of Iran in 1960s. They are now scattered in different museums and private collections. These objects including arts of different styles such as Assyrian, Urartian, Scythian and native cultures, has long been subject of various discussions among scholars concerning their stylistic and chronological evaluations such as Andre Godard [17-19], Roman Ghirshman [16, 14] Barnett [4-6] Robert Dyson [12] Helen Kantor [22], Charles Wilkinson [40], Oscar White Muscarella [26] and, Porada [33]. Some of the Ziwiye finds which consisted of gold plaques, presumably belt fragments, are included in this study. While attribution of these incomplete fragments as belts is not confirmed yet and may have multitude of functions, comparison by parallel examples found in situ on skeletons and the complete belts as well as pictorial and sculptural representations and, as Moorey mentions about the Luristan examples, "consideration of their size" [25] would play an important part in their attribution as belt fragments. The fragments presented here are representative of about 4 incomplete belts including 3 gold belts and 1 bronze belt. All of them have been individually published in some publications but a comprehensive study on them is still lacking. The identical characteristics of these belts are their rectangular forms with varying height and sizes. Their perforated borders which are demonstrative of their inner linings, probably made of a different material. The elaborate overall human and animal designs rendered vividly on the belts from Ziwiye. These figures are executed either in repousse or chased techniques within a simple or guilloche frame in one or more registers. The most important characteristic of these belts is the variety of figurative styles can be traced on them and the symmetry of designs which is the most important characteristic of ancient Near Eastern arts in that period.

Difficulties in studying these belts is that no complete belt has been found until now and base on the existing dispersed pieces, it is somehow impossible to study the technological evolutions of them and to establish their chronological evolution process. The grouping of the belts, in this study, has been done according their decorations as well as figurative characteristics on them and their execution style, in which comparing with the parallel examples from nearby cultures would serve as a clue to perceive developments, centers of manufacture and their chronological frame works as well. 


\section{First belt}

The first belt is a narrow gold strip of which only two fragments have been published yet. The longest fragment is about $34.5 \mathrm{~cm}$ length and about $5.5 \mathrm{~cm}$ height but the small plate's dimension has not been mentioned. The total length base on these limited fragments is undetermined. These fragments were published by Ghirshman and are now in a private collection's possession (Figure 1) [19].

The belt is a rectangular gold strip with rounded corners. Its borders have been perforated by double punched holes in regular intervals. It might be attached to a lither or fabric lining. Although it is impossible to study the exact manufacturing techniques used in making process of this belt, the technique would not be so far different from the ways used today by traditional metal workers in the area. At the very first stage, the gold is hammered flat into a shape of a continuous strip, then probably it was cut in to the desired shape and form. And finally the chased decorations have been executed on them. These decorations could have been chased by chisels with various points hammered on the face side of the sheet.

A total of 15 human figures are represented on this belt within a guilloche framed procession (Figure 1). These figures are dressed in long fringed robes belted in the waist. They are wearing ankle length trousers and hoods flanked by two bands. These male figures are wearing two hanging tasseled scarves often swing out from behind them. These aligned people probably are depicting a formal or ritual ceremony.
On the first fragment (Figure1.a) the scene, scheduled from left to right, represents a stylized tree flanked by two men on either side. Each man is raising one hand and holding a lion, face down by its leg, in the other. These are followed by three men proceeding toward them. These men are carrying spear like objects in their right hand and a fish in the left. Behind these three men a man, which is rendered enface, is holding two opposed lions in his arms. He presumably represents "Gilgamesh". This man is flanked by two men who are carrying fish in one hand and raised the other hand towards him. This scene is probably representative of a sacrifice ceremony to a god. On the second fragment the figures are rendered proceeding to left (Figure1.b). The scene begins with an armed man with a dagger in his right hand. He holds a lion, face down of his leg, in his left hand. On the opposed side another armed man holding the lions left leg is killing another lion by his dagger. The lion is fighting another armed man. In their opposed side a lion standing on his back legs struggling with two men on either sides. The left person holds a goat face down in his left hand. This register ends in a man looking right, is carrying a fish in his left hand. The iconographical features of the men in these fragments are their enface bodies and heads in profileexcept the man representing Gilgamesh- with big eyes, prominent hooked nose, short tidy bearded face. The animals like men are rendered vividly with big eyes and gaping jaws, the body details are stylized; shoulders are shown in double incised lines and the rib-cage is emphasized.

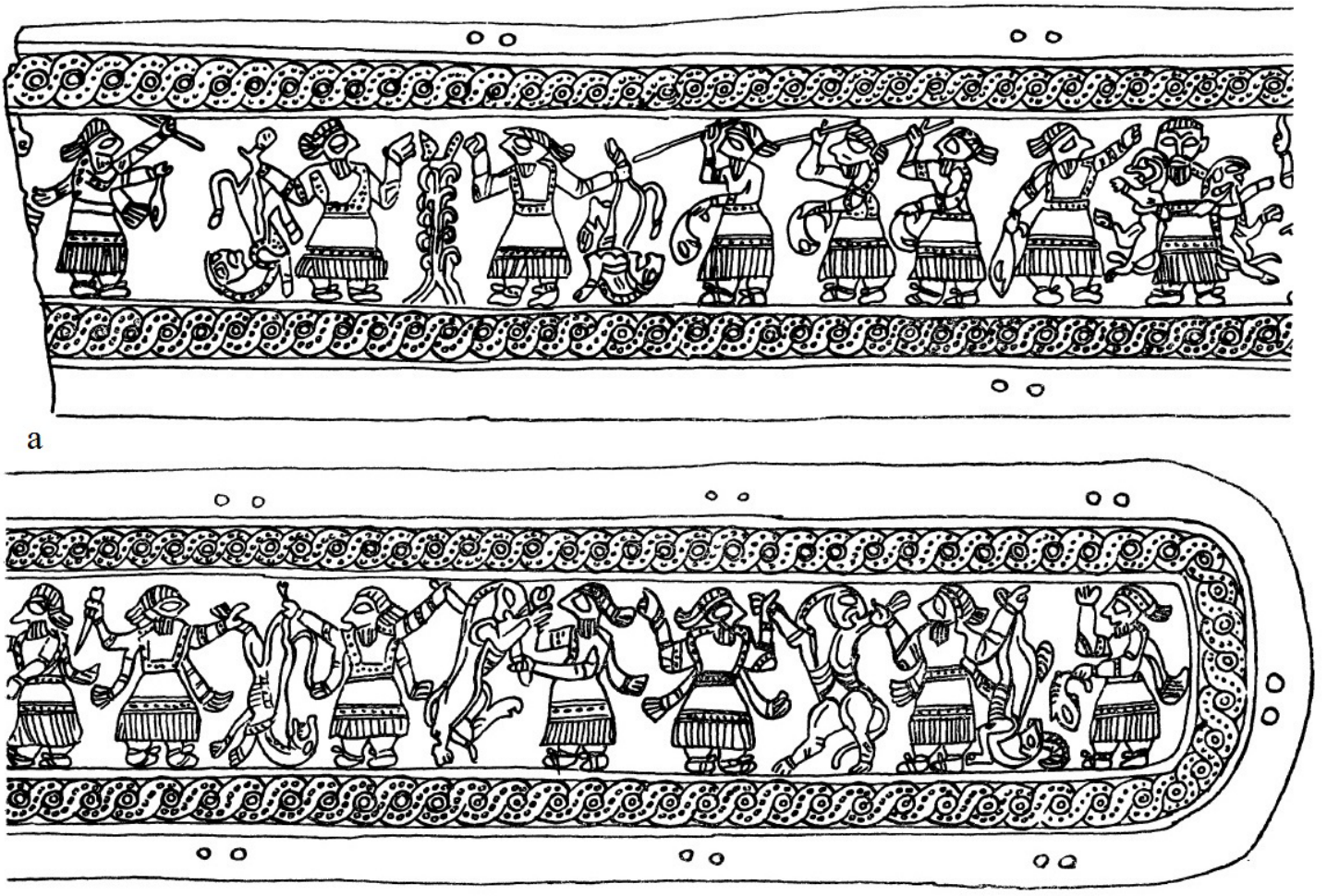

$\mathrm{b}$

Figure 1. Ziwiye Gold belt fragments, Private Collection (Ghirshman, 1950: 194- 195, fig.19) 


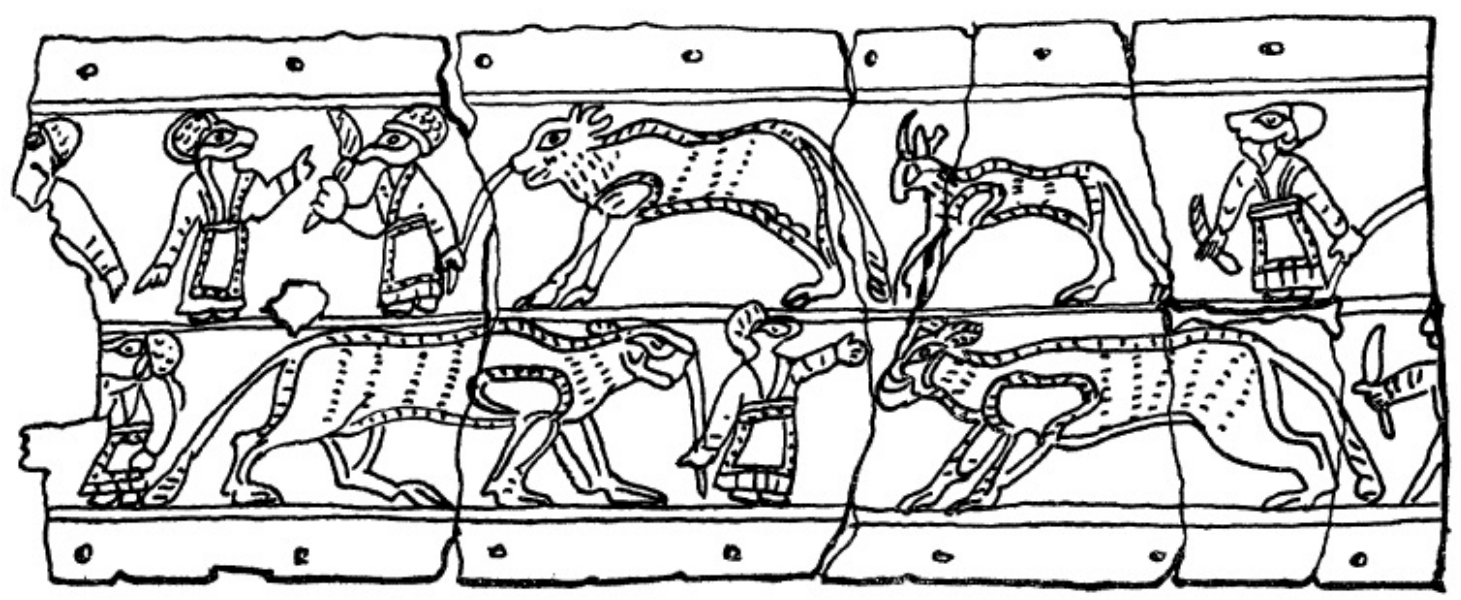

Figure 2. Ziwiye gold belt fragment, Private Collection (Ghirshman, 1950: fig. 20)

\section{Second Belt}

The second belt is made of a very thin hammered gold strip. The only fragment of this belt, published by Ghirshman $[19,15]$. It now belongs to a private collection.

On this belt, some tributaries represented within two horizontal parallel registers rendered in chased technique by hammering the chisel on the face side of the plate. The figures, while leading animals, are proceeding from left to right in both registers (Figure 2). The men dressed in long belted robes and simple hoods on head. On the upper register the first person on the left is holding a rein, probably to lead an animal; he is carrying a rod in his right hand. After him, a striding horned animal- seemingly a goat- is rendered in profile. The next figure is a lion, leading by a man with a rein attached to its muzzle, this person, with raised rod, is talking to a man preceding him and turned back. This scene recalls the tributaries in Persepolis reliefs.

In the lower register, from left to right, there is an aggressive lion which probably is proceeding by a man carrying a rod. The lion is moving towards a man turned back. This man is leading a lion by a rein attached to its muzzle. The last figure is a partial figure proceeding to right. Men and animal are rendered vividly on this belt. The human figures are chased with body en face and the head in profile with straight prominent hooked noses and big eyes with no chin or lips. While the striding animals, are rendered in profile with the bodies drawn with a double hatched perimeter margin. Their body hair is rendered by bands of dashes. The shoulders are shown in double hatched lines and the long tails are pointing down.

This belt is framed in simple relief lines and is perforated by small punched holes probably to attach to an inner lining. The iconographical features of this belt: enface bodies and heads in profile with big eyes and prominent noses, thin lips and hatched beards, all can be paralleled in "Luristan bronze works" specially on the disk headed bronze pins [25] and the iconographical traditions in Hasanlu IV as well [41]. These figures' clothing is also the most popular of Luristan bronze works with the same fringed robes and hoods [20], and on ivories from Ziwiye [36]. The comparable scenes of men and animals in combat, especially the men fighting lions and holding goats of their legs occur on a silver beaker from Luristan dated to the $8^{\text {th }}$ to $7^{\text {th }}$ centuries B.C. [36]. The representations of the animal hair, shoulders and emphasized rib- cages, the so-called "Western Iran Zoomorphic Elements" characteristics as Moorey mentioned [25] can all be seen on these belts.

\section{Third belt}

This belt is a bronze strip with the height of about $14.5 \mathrm{~cm}$ with rounded ends, while its length remains unknown. To make this belt, first the bronze has been fired red and then hammered in to a continuous strip. This strip has been cut into a rectangular strip with rounded corners (Figure 3). This belt is decorated by some loosely rendered horned animals, seemingly bulls. These animals are executed in simple linear technique by a chisel hammered on the face side of the plate. The vividly rendered figures are separated by regular intervals from one another. They are aligned within two parallel horizontal bordered bands by common guilloche. The striding bulls which are represented in chased, are shown with horns pointed forward and tails pointed down at a sharp angle to the back line. The body's details are stylized, shoulders are shown in simple incised lines and the rib-cages are emphasized. The faces of the bulls are smooth and plain except the lines indicating the eyes, mouth and the nose.

The only fragment of this belt has been published by Ghirshman and now belongs to a private collection [19]. The horned striding bulls on this belt, represent some parallel iconographical features can be seen on some Urartian bronze works. These bulls are also rendered in simple linear techniques on a bronze mirror [6], and on an Urartian shield of Argišti I from Karmir- Blur [32]. These bulls have been rendered on some bronze horse trapping, horse gears [24], and chariot disks [29] while a god or a divine character is standing on them. 


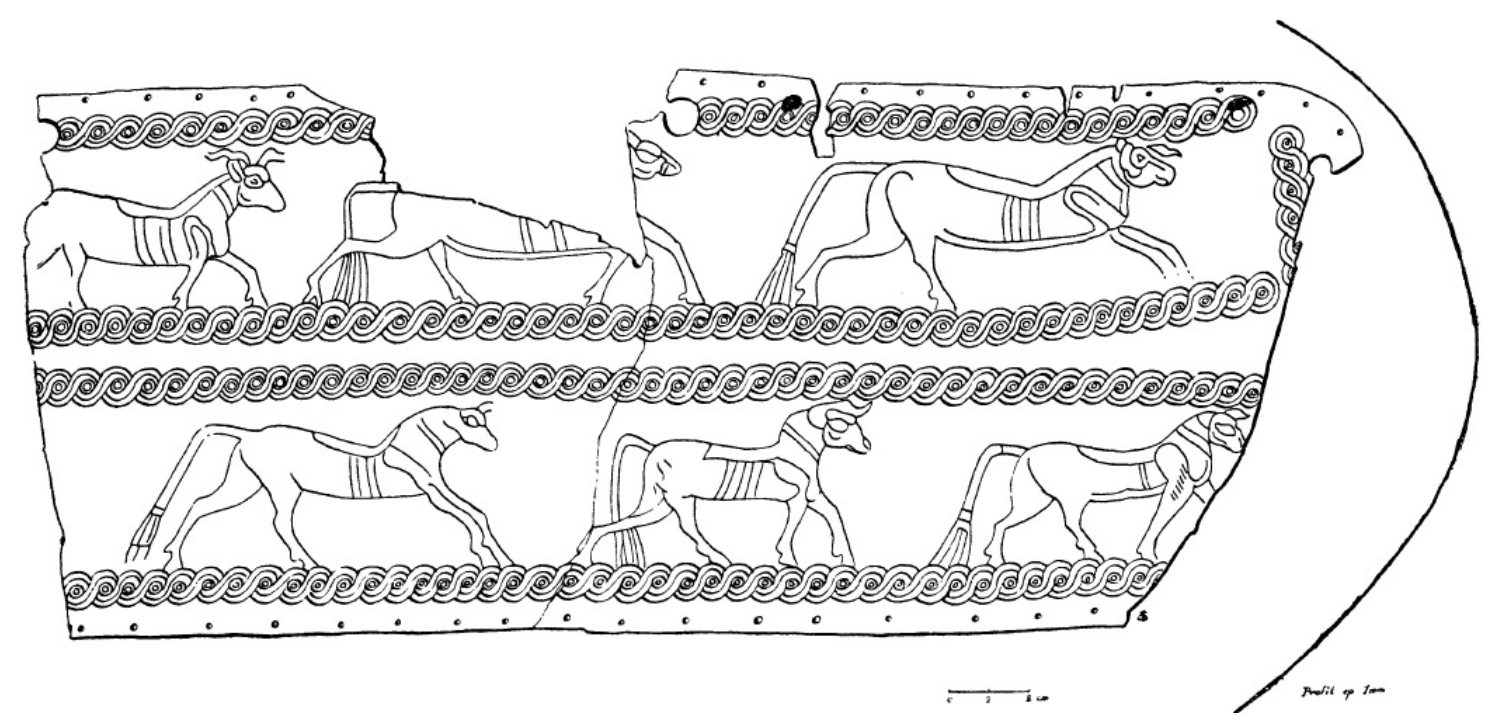

Figure 3. Ziwiye bronze belt fragment, private collection (Ghirshman, 1950, fig. 22)

\section{Forth belt}

The most known of Ziwiye belts is a heavy gold strip in numerous fragments. These fragments are now dispersed in various collections. Until now, about 10 pieces of this belt have been published in various publications. The first is in a private possession [1]. The second fragment now belongs to Davis Museum of Art in St Louis, the other is in Iran National Museum in Tehran, which first was published by Godard [19] another fragment now is in British Museum possession [4], the next fragment in Iran National Museum published by Ghirshman [15], sixth fragment published in Pennsylvania University Museum Bulletin, the seventh fragment belongs to a private collection [1], the next belongs to a private collection and was published by Ghirshman [16], and the last is kept in Metropolitan Museum of Art [40] (Figure 4).

These various fragments represent a rectangular belt to the height of about $16 \mathrm{~cm}$ with straight ends and perforated borders by small punched holes for attaching to a leather or fabric lining. The total length of this belt is still unknown because of the limited known fragments. Like previous gold examples during making process of this belt the gold is hammered flat then cut in to a rectangular continuous strip with straight corners. According the survived pieces, the main decoration on the belt is a network pattern, resembling tree branches, with recumbent stags and goats, in the hollow fields in alternate rows. These figures are executed in repousse technique with chased details. The meeting points of the nets are joining by lion masks, all of which were rendered in relief with chased details. These figures, repeated several times on the belt, probably were rendered with a cliché or model of the design carved on stone or wood. At first an outline model of the figures was carved on a stamp model, which was then hammered through to define the design on the front face of the sheet. The details, then were rendered by a pointed chisel on the front face of the belt. So we can say that the stags, goats and the trees could have been executed in the same method on these belts as well as on other metal works of the Ziwiye finds.

This distinctive decoration of network pattern on this belt is paralleled to the Urartian belts with the same net reported from Zakim, Karmir- Blur, Ani- Pemza and Altin Tepe and the so-called belt of Giymili Hoard [1, 4, 24, 15], while the recumbent stags and goats rendered on this belt are closely resemble the figures in co-called "Scythian animal style". Closely parallel examples of these goats and stags with the same iconographical features such as double brow-tine antler, stretching over the length of the body, carefully head and eye modeled, double outlined shoulder and hind leg, and slightly bent under legs reoccur in Transcaucasia in the $6^{\text {th }}$ century B.C., on a battle axe from Kelermes [23, 31] and Kuban [23, 4, 39, 15, 31, 21, 34]. The Urartuan-Scythian pattern adoption in this belt and the comparable examples from Urartian sites had served as the clue for Amandry in his reconstruction of the belt [1]; he has recommended a gold plate measuring $14 \mathrm{~cm} \times 5.5 \mathrm{~cm}$ as the right end of the belt. This fragment, which was first published by Ghirshman [15], is decorated by a tree of life; crowned by a palmette in repousse. The ringed trunks are flanked by two lions and at the top there are two other recumbent lines [1] (Figure 4). This would consist the central motif of the belt when worn. 

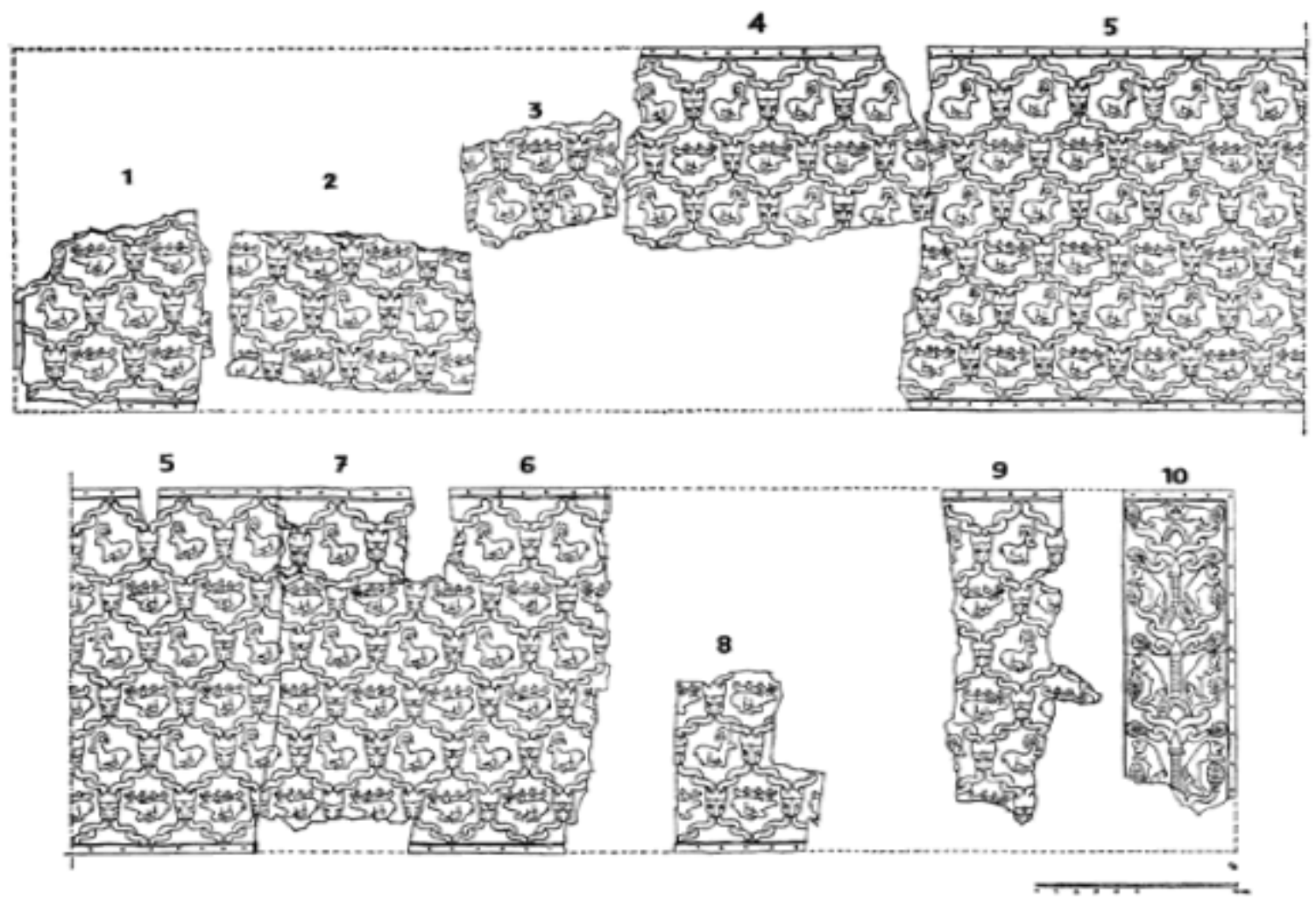

Figure 4. Ziwiye gold Belt, reconstructed by Amandry (Amandry, 1966: fig.4)

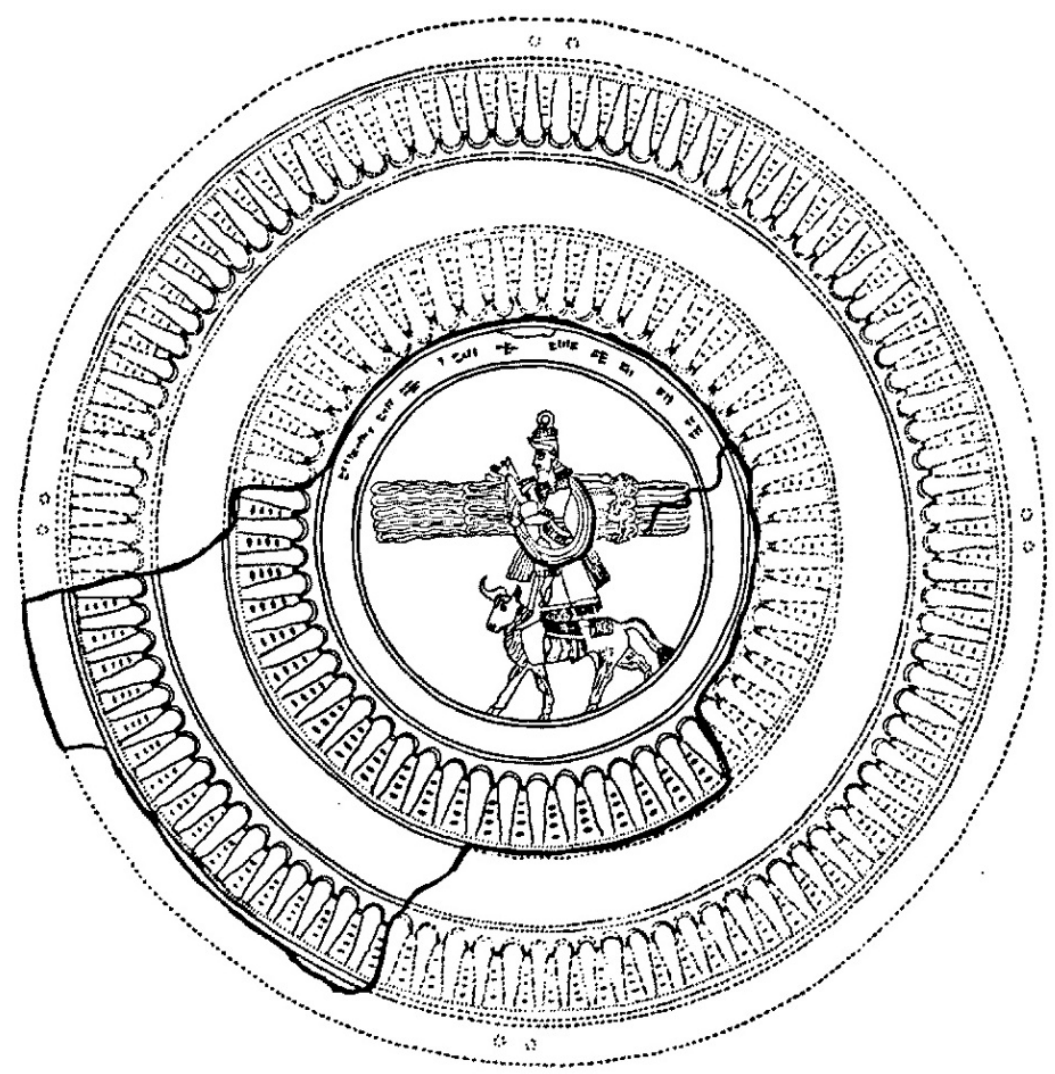

Figure 5. Bronze chariot disk (Merhav, 1991: 98, Fig. 13.3) 


\section{Discussion and Conclusions}

Despite the very limited number of belts from Ziwiye, these belts could be grouped and studied in different groups based on the scenes depicted on them and their iconographical features.

Based on these features these belts could be studied in three main following groups:

1. The first group chronologically stands earliest group. Belts with ritual or ceremonial scenes in the form of a team or group of offering bearers are placed in this group. Both the decorations and the material used to make them are representative of their formal or ceremonial functions. Their iconographical features can be exactly paralleled in Luristan bronze works especially on disk-headed pins. The characteristics which also can be traced on the ivories from Hasanlu IV [12] and on Hasanlu gold bowl [41]. Based on these examples belts in this group can be dated to the first quarter of the first millennium B.C. or to the $8^{\text {th }}$ century B.C., while the other fragments by narrative scenes from different provenances in Iran are mainly dated to the first half of the first millennium B.C. or to the $8^{\text {th }}$ and $7^{\text {th }}$ centuries B.C. although none of these belts have been recovered during controlled excavations [27] and they cannot be assigned to a specific time span, but according these comparisons they can't belong to a time later than $9^{\text {th }}$ to $8^{\text {th }}$ centuries B.C.

2. The second group with the frieze of long passant horned bulls, are completely distinct among Ziwiye belts. This is the only bronze belt from Ziwiye published until now. The crudely rendered horned bulls and the material the belt has been made of may include it as objects of daily use. Similar bulls can be seen on some Urartian objects such as hoarse gears and trappings inscribed with the name of Menua (810- 785/ 78 B.C.) [24]. In the center of a bronze chariot disk with the name of Išpuini (ca. 830- 810 B.C.) [29] there is a god or a divine character standing on a similar bull (Figure 5). On a bronze shield from Karmir-Blure, similar bulls are represented in the form of a circle frieze. This shield is inscribed by the name of Argišti I (c. 786- 746 B.C.) [32]. Based on comparisons these belts could be interpreted as equipment of soldiers or huntsmen in $8^{\text {th }}$ to $7^{\text {th }}$ centuries B.C. this date, however, can't be confirmed until more definite data come to light.

3. The third group of Ziwiye belts which is the best example of mixture of Scythian and western Asiatic elements found in Ziwiye [6]. The earliest and the most popular examples of the network patterns, represented on this belt, appear in Urartu ornamental art since $9^{\text {th }}$ to $7^{\text {th }}$ [7] or probably to the latest phase of the the urartian art towards the end of the seventh and the beginning of the sixth century B.C. [2] while the zoomorphic features of the stags and goats on Ziwiye belt could be paralleled in the art of the $6^{\text {th }}$ century B.C. in Scythia, so this belt can't be earlier than $6^{\text {th }}$ century B.C. These nets varying from 3 rows up to 5 rows in Urartian bronze belts reach the widest case in Ziwiye to 6 rows [7] and the Ziwiye craftsmen adopting primitive Scythianwestern Asiatic artistic elements represent it's more sophisticated form in Ziwiye belt in $6^{\text {th }}$ century B.C. so this belt chronologically stands the latest group among the belts from Ziwiye. Although the function of this belt because of the limited documents is obscure yet but Urartian examples found in situ in inhumation burial excavated in 1958 at Tli and their extensive length may be representative of their actual functions [2].

Although these limited fragments with various artistic elements make these belts attribution to a specific artistic style, in all of them both in material and the scenes represented on them reveal the Iranian local tradition of metal workshops, while the questions such as if they were belonging to the males or females, or whether they are made for ceremonial or as armors for warriors as well as their manufacturing techniques remain still obscure, until we could achieve to various dispersed pieces with in the different museums and collections all over the world to do through technological studies or to get to the parallel examples from controlled excavations.

\section{REFERENCES}

[1] Amandary, P. (1966) A Propose du Tresor de Ziwiye, Iranica Antiqua 6, 109-130.

[2] Azarpay, G. (1968) Urartian Art and Artifacts: A chronological Study, (Berkeley1968).

[3] Barnett, R.D. (1963), A Review of Acquisitions 1955-62 of Western Asiatic Antiquities, The British Museum Quarterly 26, No. 3/4, 92-101.

[4] Barnett, R.D (1962), The Madian Art, Iranica Antiqua 2, 77-92.

[5] Barnett, R.D (1956), The Treasure of Ziwiye, Iraq 18/2, 111-116.

[6] Barnett, R. D. (1950), Le Trésor de Ziwiyé (Azerbeidjan), Syria 27, Fasc. 1/2, 196-197.

[7] Berczi, S. (2001), On the Earlier Occurrences of the cm- Type Nets and Wallpaper Patterns in Ornamental Arts of Central Eurasia, Symmetry in Ethnomatematic, Symmetry: Culture and Science 12, No.1-2, 5-24, Hungary: International Symmetry Foundation, Budapest.

[8] Courtis, J. (2000), Ancient Persia-1, the British Museum Press (London).

[9] Courtis, J. (1988), Bronze working Centers of Western Asia, c.1000- 539 B.C., British Museum, (London).

[10] Crouwed, J.H. (1979), Early Belt-Buckle from Iran and Central Anatolia, Iranica Antiqua 9, 49-6.

[11] Culican, W. Zimmer, J. (1987), Decorated Belts from Iran and the Caucasus, Iranica Antiqua 22, 159-199. 
[12] Dyson R.H. (1963), Archaeological Scrap: Glimpses of History at Ziwiye, Expedition 5, 32-37.

[13] Ghrishman, R. (1979), Les Cienture en Iran, Iranica Antiqua 14, 167-196.

[14] Ghrishman, R. (1973), À propos du Trésor de Ziwiyé, Journal of Near Eastern Studies 32.4, 445-452.

[15] Ghrishman, R. (1964), Persia from the Origins to Alexander the Great, Thames and Hudson, (London).

[16] Ghirshman, R.H. (1950), Le Trésor de Sakkez, les origines de l'Art Mède et les bronzes du Luristan, Artibus Asiae, 13/3, 181-206.

[17] Godard, A. (1983), Der "Schatzfund" von Ziwiyah und der Ursprung des Sog. Skythischen Tierstils in Vorderasien, Iranica Antiqua 18, 97- 109.

[18] Godard, A. (1951), A Propose de Trésor de Ziwiyè, Artibus Asiae 14, No. 3, 240- 245. (Hrouda, B).

[19] Godard, A. (1950), Le Trésor de Ziwiyè, Seri Archeologique de L'Iran, (Paris).

[20] Goldman, H. (1963), Excavation at Gözlü Kule, Tarsus: Iron Age, Vol.III, (Princton).

[21] Jacobson, E. (2005), Art of Scythien, British Museum press, (London).

[22] Kantor, H.J. (1960), A Fragment of a Gold Applique from Ziwiye and Some Remarks on the Artistic Traditions of Armenia and Iran during the Early First Millennium B. C., Journal of Near Eastern Studies 19, No. 1, 1-14.

[23] Loehr, M. (1955), The Stag Image in Scythia and the Far East, Archives of the Chinese Art Society of America 9, 63-76.

[24] Merhav, R. (1991), Chariot and Horse Fitting: Chariot Accessories, Urartu a Metalworking Center in the First Millennium B.C. (ed. R. Merhav), 52-78.

[25] Moorey, P.R.S., Ryder, M.L. (1967), Some Ancient Metal Belts: Their Antecedents and Relatives, IRAN 5, 83- 98.

[26] Muscarella, O.W. (1977), Ziwiye and Ziwiye: The Forgery of a Provenience, Journal of Field Archaeology 4, 197-220.

[27] Negahban, E.O. (1995), Weapons from Marlik, Dietrich
Reimer, (Berlin).

[28] Overlaet, B.J. (1983), A Transcaucasian Belt with a Quadriga Representation, Iranica Antiqua 18, 109- 119.

[29] Özgen, E. (1983), The Urartian Chariot Reconsidred: I Representational Evidence, 9th-7th Centuries B.C., Anatolica 10, 111- 132 .

[30] Peck, E.H., (2002), A Decoreted Bronz Belt in the Detroit Institute of Arts, Leaving No Stone Unturned: essays of the ancient Near East, (London).

[31] Piotrovsky, B. Quoniam, P. (1975), Ores des Scythes: Tresors des Musees Sovietiques, Musees Nationaux, (Paris).

[32] Piotrovsky, B.B. (1967), Urartu- The Kingdom of Van and its Art, (New York).

[33] Porada, E. (1963), Iran Ancient: I'Art A l'Epoque Preislamique, Albin Michel, (Paris).

[34] Razmjou, Sh. (2005), In search of Maiden Art, Iranica Antiqua 11, 271- 314

[35] Sarkhosh, S. Stwart, S. (2005), The Birth of Persian Empire, London Middle East Institute, (British Museum Press).

[36] Shepherd, G. (1966), Four Early Silver Objects from Iran, The Bulletin of the Cleveland Museum of Art 53, No. 2, 38-50.

[37] Taşyürek, O.A. (1977), The Urartian Bronz Hoard from Giymili, Urartian Belts and the Stories They Tell, by: Alina Ayvazian, Near Eastern Art and Archaeology, (California).

[38] Taşyürek, O.A. (1975), Urartian Belts in the Adana Regional Museum, (California).

[39] Tchlenova, N.L. (1963), Le Cerf scythe, Artibus Asiae 26, No. 1, 27-70.

[40] Wilkinson, Ch. (1955), Metropolitan Museum of Art Bulletin, (New York).

[41] Winter, J.I. (1977), Perspective on the "Local Style" of Hssanlu IVB: A Study in Receptive, Bibliotheca Mesopotamia7, 371- 386.

[42] Woolley, L. (1961), The Art of The Middle East, including Persia, Mesopotamia and Palestine, Crown Publishers, (New York). 